\title{
Distribution and numbers of moulting non-breeding Whooper Swans Cygnus cygnus in the Baltic States and South Sweden
}

\author{
Geografisk fördelning och antal av ruggande icke häckande sångsvanar Cygnus \\ cygnus $i$ Baltikum och Sydsverige
}

HAKON KAMPE-PERSSON, DMITRIJS BOIKO \& JULIUS MORKŪNAS

\begin{abstract}
Non-breeding Whooper Swans Cygnus cygnus were recorded moulting for the first time in Latvia in 1989, in Estonia in 1993 and in Lithuania in 1997. Moulting has been recorded at 13 sites, three in Estonia and five each in Latvia and Lithuania, but not at all in South Sweden. The total number of moulting non-breeders increased from at least 83 birds in 2003 to at least 187 birds in 2012 . The majority of the marked birds found moulting as non-breeders in the Baltic States usually originated from moulting sites within $25 \mathrm{~km}$, the others from countries, including Germany and Poland, situated to the south of the moulting site. Distances between sites of hatching or breeding and moulting for these two groups ranged $0-81$ $\mathrm{km}$ and $191-836 \mathrm{~km}$, respectively. When caught for ring-

ing, $40 \%$ were $2^{\text {nd }}$ calendar year birds, the others older. Life-histories of Whooper Swans marked as moulters, or found moulting, in the Baltic States were used to discuss the lack of known moulting sites in South Sweden.

Hakon Kampe-Persson, Pulmaņi, Glūdas pagasts, Jelgavas novads, LV-3040, Latvia.Email: kampepersson@ hotmail.com

Dmitrijs Boiko, Natural History Museum of Latvia, Kr. Barona iela 4, Rīga, LV-1050, Latvia. Email: dmitrijs. boiko@gmail.com

Julius Morkūnas, Institute of Ecology, Nature Research Centre, Akademijos street 2, Vilnius, LT-08412, Lithuania.Email:juliusmorkunas@gmail.com
\end{abstract}

Received 26 October 2012, Accepted 20 November 2012, Editor: S. Svensson

\section{Introduction}

Feathers wear out through constant use so birds have to replace them. Most birds replace their primary and secondary wing feathers one or two at a time so that their power of flight is not drastically impaired. Swans, geese and ducks, however, shed their wing feathers all at once and consequently lose the power of flight for a period. The Whooper Swan Cygnus cygnus moults its wing feathers from late June to the middle of September and is flightless for about 5-6 weeks (Dement'ev 1935, Boiko \& Kampe-Persson 2012, Julius Morkūnas unpubl.). Among wildfowl, breeding birds usually moult their wing feathers on their breeding grounds and non-breeders in summer congregations. The Whooper Swan matures slowly and first breeding is usually at the age of 4-6 years (Einarsson 1996). A high proportion of the population therefore consists of non-breeding birds. About two thirds of the population does not attempt to breed in each year (Garðarsson \& Skarphéðinsson 1984, Haapanen 1991, Rees et al. 1991, Einarsson 1996, Schadilov et al. 2002, Brazil 2003).

Non-breeders of most swan species gather in flocks and undergo wing moult near the breeding grounds (Brazil 2003). However, Whooper Swans in the Baltic region do not fit this general pattern. No mass-moulting sites have been located in Fennoscandia; only groups of local birds numbering up to 18 individuals in large mire complexes have been recorded (Haapanen 1991, Leif Nilsson in litt.). These groups cannot account for all non-breeding birds, as the number of breeding pairs in Sweden and Finland numbers more than 10,400 (Väisänen et al. 2011, Ottosson et al. 2012). It is surmised that the Fennoscandian birds moult in highly productive wetlands in Russia (Beekman 1998), most likely in the Arkhangelsk Region (Boiko \& Kampe-Persson 2012) but, except for one Finnish bird found moulting on the Kanin Peninsula (Litvin \& Gurtovaya 2003) and three Latvian birds found moulting in the Arkhangelsk Region (Boiko \& Kampe-Persson 2012), concrete evidence is lacking (Fransson \& Pettersson 2001, Valkama et al. 2012). In the Baltic States and Poland, on the other hand, there is at least one moulting site for more than 20 individuals in each country (Luigujõe et al. 2002, Boiko 2008, Wieloch \& Sikora 2008, Morkūnas et al. 2010).

Non-breeding Whooper Swans that moult in the Baltic States may be birds unable to undertake a 
moult migration to Russia. Injured birds and birds in poor physical condition, unable to carry through a long-distance migration, are often forced to remain where they are. There are several examples of geese having both bred and moulted in their winter quarters (Kampe-Persson 2010). Also Whooper Swans from naturalised populations, for instance the German (Bauer \& Woog 2008), might moult in the Baltic States. Other reasons for species to change their traditional northern moulting grounds in favour of areas situated closer to the breeding grounds are overpopulation in the traditional moulting areas, changes at southern latitudes promoting moulting there and chance events.

The number of Whooper Swans breeding in South Sweden, the part of Sweden situated at the

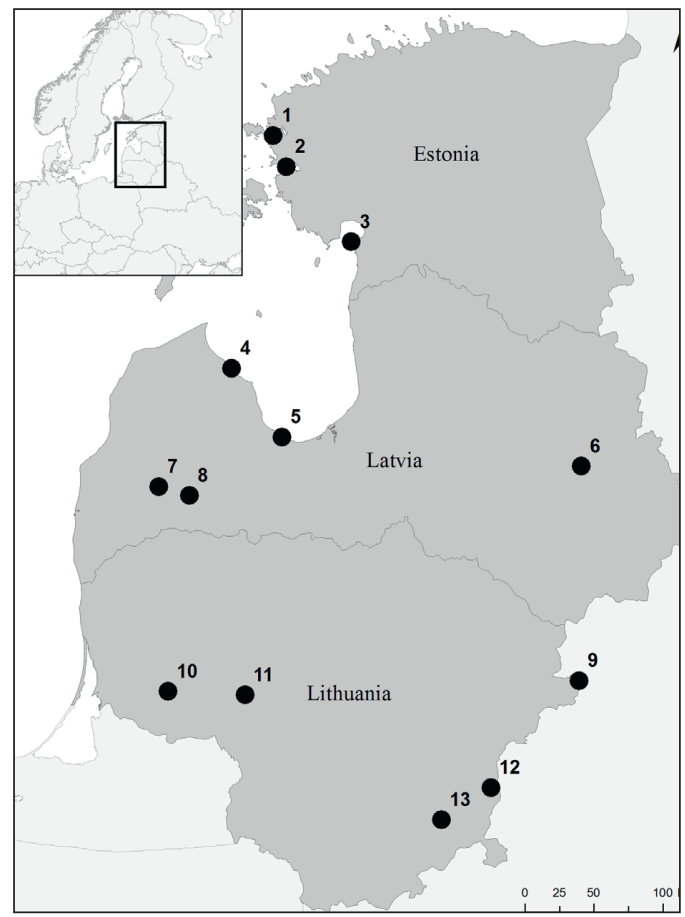

Figure 1. Sites in the Baltic States where moulting of nonbreeding Whooper Swans have been recorded. 1. Hapsalu Bay, 2. Matsalu Bay, 3. Pärnu Bay, 4. Kaltene (Riga Bay), 5. Lake Kanieris, 6. Nagli fishponds, 7. Skrunda fishponds, 8. Satini fishponds, 9. Baltoji Voke fishponds, 10. Raseiniai fishponds, 11. Visbarai fishponds, 12. Birveta fishponds, 13. Akvilegija fishponds.

Lokaler i Baltikum där ickehäckande sångsvanar har konstaterats rugga. 1. Hapsalubukten, 2. Matsalubukten, 3. Pärnubukten, 4. Kaltene (Rigabukten) 5. Kañierissjön, 6. Nagli fiskdammar, 7. Skrunda fiskdammar, 8. Satini fiskdammar, 9. Baltoji Voke fiskdammar, 10. Raseiniai fiskdammar, 11 . Visbarai fiskdammar, 12. Birveta fiskdammar, 13. Akvilegija fiskdammar. same latitudes as the Baltic States, increased from about 650 pairs in 1997 (Axbrink 1999) to about 800 pairs in 2011 (Ottosson et al. 2012). The increase in the non-breeding segment of the population during the same period of time is estimated to have been from about 2,600 birds to about 3,200 birds. In spite of such large numbers of non-breeding birds, there are no known moulting sites in South Sweden (Leif Nilsson in litt.).

Species that moult all flight feathers at the same time have two main requirements while they are flightless: a supply of nutritious food and safety from predators. Areas fulfilling these requirements are for most larger-sized species found north of their breeding grounds. Long-distance moult migration is the norm among geese (Owen 1980) but has only recently been documented in the Whooper Swan (Boiko \& Kampe-Persson 2012). The Kanin Peninsula, moulting area of importance for more than a century (Dement'ev 1935, Litvin \& Gurtovaya 2003, Alexander Kondratyev \& Konstantin Litvin pers. comm.), is a good example of what the moulting Whooper Swan requires. Except in the north, the peninsula is a flat, low-lying, marshy tundra plain, rich in food for the swans, unpopulated and impossible to access on foot or by boat. Though much smaller in size, the large mire complexes used for moulting in Fennoscandia resemble the afore-mentioned area. In South Sweden, the large number of breeding Whooper Swan pairs evidence the existence of potential moulting sites, because breeding birds moult their wing feathers while rearing young. The Whooper Swan is strongly territorial, however, and defends a nest site and an area around it for the pair and their young to feed in (Kear 1972). Other swans are of that reason rarely found in a water-body where a Whooper Swan pair breeds. Are there any other suitable sites?

Our aim was to give a complete description of distribution and numbers of moulting non-breeding Whooper Swans in the Baltic States, and to make a preliminary analysis of the life-histories of individuals marked, or marked individuals found moulting, at the different moulting sites in these countries. Finally, we wanted to know if a combination of these data could elucidate why there is no known moulting site for non-breeding Whooper Swans in South Sweden.

\section{Material and methods}

Pre-moult, moult and post-moult periods were defined as 1 May-28 June, 29 June-14 September and 15 September-31 October, respectively (Boiko 


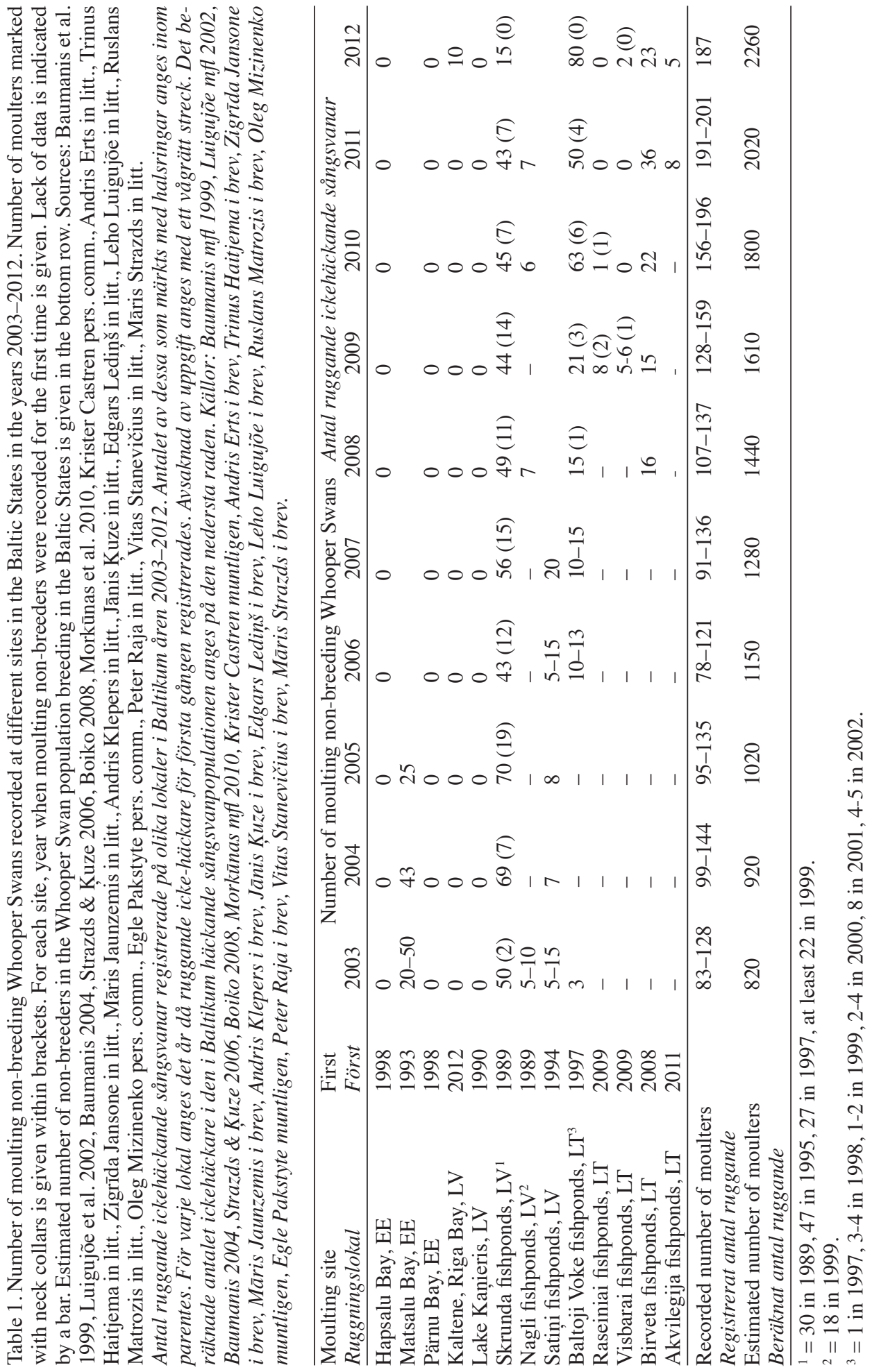


\& Kampe-Persson 2012) and the moulting season as 1May-31 October.

Information on the numbers of moulting nonbreeding Whooper Swans at different sites in the Baltic States were obtained from a literature search and from field surveys. Fieldwork was undertaken in Latvia by the second author (DB) during the years 2003-2012 inclusive and in Lithuania by the third author (JM) during the years 2008-2012 inclusive. Supplementary data were obtained from ornithologists.

A total of 94 non-breeding Whooper Swans caught in Latvia, 18 in Lithuania and two in Estonia were fitted with neck collars through 2012 (Table 1). The vast majority of these were ringed at Skrunda fishponds in western Latvia (Table 1, Figure 1). All birds were at ringing divided into two age categories, $2^{\text {nd }}$ calendar year and adult. Each collar had a 4-digit alphanumerical code readable at a distance of 50-300 m with a 20-60x telescope under normal field conditions. Similarly, a total of 45 breeding adults and 604 cygnets caught in Latvia were fitted with neck collars during 20042010. The range of sites where breeders and cygnets were caught reflects the breeding distribution of the species across Latvia (Boiko \& Kampe-Persson 2010). In Lithuania, 9 breeders and 136 cygnets were collared during 2008-2010 (Morkūnas et al. 2010). Similar ringing projects started in Poland in 1983 (Wieloch \& Czyź 2008) and in Germany in 1998 (Degen \& Heinicke 2007).

Re-sightings of birds marked in Latvia were generated by appealing for information on the home page of the Latvian Ornithological Society (LOB) and on the "European colour-ring birding" website www.cr-birding.be. Between November 2008 and March 2010 observers were asked to enter their resighting data via the colour ring reporting website www.cr-birding.nl, and from April 2010 onwards via www.geese.org. Re-sightings of Lithuanian birds were obtained by reports to the project coordinator (JM) and from November 2011 onwards via www.geese.org. Re-sightings obtained up to 25 October 2012 were used in the analyses.

Based on life-history data a logical division of all Whooper Swans marked as non-breeders in the Baltic States through 2012 were done by allocating them to categories in the following order: 1. marked in 2011 or 2012 (no useful data yet), 2. not re-sighted after ringing, 3 . not re-sighted after the moulting season, 4 . found moulting and breeding in the years after ringing, 5 . found moulting in the years after ringing, 6 . found breeding in the years after ringing, 7. re-sighted during the pre- and post-moult peri- ods, 8. re-sighted during the pre-moult period, 9 . re-sighted during the post-moult period, 10. none of the afore-mentioned categories. Categories 5, 6 and 9 were divided into subcategories. Life-histories of other marked Whooper Swans found moulting in the Baltic States were also analysed, especially in relation to origin and age at marking.

Estimates of the number of individuals in the Whooper Swan population of the Baltic States that did not attempt to breed in each year were obtained by using the latest available estimates of the number of Whooper Swan pairs breeding in each of the Baltic States (Luigujõe et al. 2002, Boiko 2005, Elts et al. 2009, Boiko \& Kampe-Persson 2010, Anonymous 2011, Butkauskas et al. 2012), assuming a constant annual population increase during the years 2003-2012 and that two thirds of the population did not attempt to breed in each year (Garðarsson \& Skarphéðinsson 1984, Haapanen 1991, Rees et al. 1991, Einarsson 1996, Schadilov et al. 2002, Brazil 2003).

\section{Results}

In the Baltic States, non-breeding Whooper Swans have always moulted together with Mute Swans Cygnus olor, where the Mute Swan flocks have numbered up to 800 birds at the coastal sites and up to 300 birds in the fishpond complexes (Trinus Haitjema in litt., Dmitrijs Boiko unpubl., Vitas Stanevičius unpubl.). Hapsalu Bay, Matsalu Bay, Pärnu Bay and Kaltene (Riga Bay) are coastal sites and Lake Kanieris a formerly drained lake, while other sites in Latvia and all sites in Lithuania are fishpond complexes (Figure 1). Matsalu Bay, Lake Kanieris and the fishponds are large and comparatively shallow (depth 1-2 m) water-bodies fringed with reed-beds and scrub outgrowth of varying width (Švažas \& Stanevičius 2000, Strazds \& Kuuze 2006, Boiko \& Kampe-Persson 2010, Meriste et al. 2012). Feed used for fish cultivation forms the major part of the diet of the moulting swans in the fishponds (Švažas \& Kozulin 2002). In most fishponds, the owners start to provide grain to the carps in the end of April or the beginning of May but at Skrunda not until June (Dmitrijs Boiko unpubl., Vitas Stanevičius unpubl.). The feeding of the carps starts while most non-breeding Whooper Swans still are in the Baltic States. Of birds undertaking a moult-migration to Russia, the last individuals usually leave in the middle of June (Boiko \& Kampe-Persson 2012). Due to restricted public access the impact of human disturbance is low in the fishponds (Švažas \& Kozulin 2002). 
Non-breeding Whooper Swans were recorded moulting for the first time in Latvia in 1989, in Estonia in 1993 and in Lithuania in 1997 (Table 1). The total number of moulting non-breeders in the Baltic States increased from at least 83 birds in 2003 to at least 187 birds in 2012. During the years 2003-2012 the total number of moulters was stable around $10 \%$ of the estimated number of nonbreeders in this population. Moulting has been recorded at 13 sites in the Baltic States but only five of them were used annually during the years 20032012. During this decade, the number of moulters increased continuously at Baltoji Voke but was quite stable, with only minor between-year fluctuations, at the other four sites. Only three moulters were recorded in Skrunda fishponds in July 2012, a year when the feeding of the carps did not start until about 23 June and there were five breeding Whooper Swan pairs compared to only $0-3$ pairs in the years 2003-2011. In August, the number suddenly increased to 45 birds at this site. Similar increases in numbers were noted in other fishpond complexes in August 2012; from seven to 29 birds at Nagli, from 20 to 40 birds at Satini, from 80 to 128 birds at Baltoji Voke and from 23 to 83 birds at Birveta. Some of the late-arriving birds moulted in the fishponds but the majority had moulted their wing feathers before joining the moulting flock.

Of moulting non-breeding Whooper Swans caught for ringing in the Baltic States, 33\% (N=94) in Latvia and $67 \%(\mathrm{~N}=18)$ in Lithuania were $2^{\text {nd }}$ calendar year birds and $61 \%(\mathrm{~N}=69)$ of the adults and $60 \%(\mathrm{~N}=43)$ of the $2^{\text {nd }}$ calendar year birds were males (Table 2). Of moulters collared up to 2010, $10 \%(\mathrm{~N}=63)$ of the adults and $8 \%(\mathrm{~N}=38)$ of the $2^{\text {nd }}$ calendar year birds were not re-sighted after marking and another $2 \%$ and $8 \%$, respectively, were not re-sighted after the moulting season. Of those that survived into the following winter, $33 \%(\mathrm{~N}=90)$ returned to moult at the moulting site where they had been marked, some of them up to five times. Another $16 \%$ of the surviving birds used the moulting

Table 2. Non-breeding Whooper Swans marked with neck collars in the Baltic States up to 2012 divided on categories according to life-history data, primarily for the pre-moult, moult and post-moult periods (for definitions of categories, see Material and Methods). $\mathrm{A}=$ the site where the bird was marked with a neck collar. Sources: Skrunda - Dmitrijs Boiko unpubl.; Lithuania - Julius Morkūnas unpubl.; Estonia - Peter Raja in litt.

Ickehäckande sångsvanar halsringmärkta i Baltikum fram till och med 2012 fördelade på kategorier baserade på observationer gjorda efter märkningen, i första hand tiden före, under och efter ruggning (för definitioner av kategorier, se Material and Methods). A = lokalen där fågeln halsringmärktes. Källor: Skrunda-Dmitrijs Boiko opubl.; Litauen - Julius Morkūnas opubl.; Estland - Peter Raja i brev.

\begin{tabular}{|c|c|c|c|c|c|}
\hline \multirow{4}{*}{$\begin{array}{l}\text { Category according to life-history data } \\
\text { Kategori enligt observationer gjorda efter märkning } \\
\text { Age at ringing: } \\
\text { Ålder vid märkning: }\end{array}$} & \multirow{2}{*}{\multicolumn{2}{|c|}{$\begin{array}{l}\text { Skrunda } \\
\text { Skrunda }\end{array}$}} & \multirow{2}{*}{\multicolumn{2}{|c|}{$\begin{array}{r}\text { Lithuania } \\
\text { Litauen }\end{array}$}} & \multirow{4}{*}{$\begin{array}{l}\text { Estonia } \\
\text { Estland }\end{array}$} \\
\hline & & & & & \\
\hline & $\mathrm{Ad}$ & 2 cy & Ad & 2 cy & \\
\hline & Ad & $2 \mathrm{~K}$ & Ad & $2 \mathrm{~K}$ & \\
\hline No re-sightings after ringing Ej sedd efter märkningen & 6 & 2 & 0 & 1 & 0 \\
\hline No re-sightings after moult Ej sedd efter ruggning & 1 & 3 & 0 & 0 & 0 \\
\hline Moulted in A, bred in Latvia Ruggade i A, häckade i Lettland & 1 & 0 & 0 & 0 & 0 \\
\hline Moulted in A and Poland Ruggade i A och Polen & 1 & 0 & 0 & 0 & 0 \\
\hline Moulted in A and Finland Ruggade $i$ A och Finland & 0 & 1 & 0 & 0 & 0 \\
\hline Moulted in A Ruggade i A & 16 & 9 & 1 & 1 & 0 \\
\hline Moulted in Poland Ruggade i Polen & 1 & 0 & 1 & 0 & 0 \\
\hline Moulted in Estonia Ruggade $i$ Estland & 1 & 0 & 0 & 0 & 0 \\
\hline Bred in Latvia Häckade i Lettland & 3 & 2 & 0 & 0 & 0 \\
\hline Bred in Lithuania Häckade i Litauen & 0 & 0 & 1 & 1 & 0 \\
\hline Bred in Belarus near Latvian border Häckade $i$ Vitryssland & 0 & 0 & 0 & 0 & 1 \\
\hline Sighted in A before and after moult Sedd i A före och efter ruggning & 1 & 0 & 0 & 1 & 0 \\
\hline Sighted in A before moult Sedd i A före ruggning & 2 & 4 & 0 & 2 & 0 \\
\hline Sighted in A after moult Sedd $i$ A efter ruggning & 3 & 1 & 0 & 0 & 0 \\
\hline Sighted in Latvia after moult Sedd i Lettland efter ruggning & 0 & 0 & 0 & 1 & 0 \\
\hline Sighted in Finland after moult Sedd $i$ Finland efter ruggning & 0 & 0 & 0 & 0 & 1 \\
\hline Neck-collared in 2011 and 2012 Halsringmärkta 2011 och 2012 & 6 & 1 & 0 & 4 & 0 \\
\hline None of the categories above Ingen av kategorierna ovan & 21 & 8 & 3 & 1 & 0 \\
\hline Total numbers neck-collared individuals Summor halsringmärkta & 63 & 31 & 6 & 12 & 2* \\
\hline
\end{tabular}

* = marked in 2001. Märkta 2001. 
Table 3. Whooper Swans fitted with neck collars as cygnets or breeders and subsequently found moulting in the Baltic States, up to 2012 . $\mathrm{Km}=$ distance in $\mathrm{km}$ between ringing and moulting sites.

Sångsvanar som halsringmärkts som ungar eller häckare och därefter funnits ruggande i Baltikum till och med 2012. Km = avstånd $i \mathrm{~km}$ mellan märknings- och ruggningslokal. cygnet $=$ unge, breeder $=$ häckare, Latvia $=$ Lettland, Lithuania $=$ Litauen, Estonia $=$ Estland, Poland $=$ Polen, Germany $=$ Tyskland .

\begin{tabular}{|c|c|c|c|c|c|c|c|}
\hline \multicolumn{4}{|c|}{$\begin{array}{l}\text { Ringing data } \\
\text { Ringmärkningsuppgifter }\end{array}$} & \multicolumn{3}{|c|}{$\begin{array}{l}\text { Moulting data } \\
\text { Ruggningsuppgifter }\end{array}$} & \multirow[t]{2}{*}{$\begin{array}{l}\text { Comment } \\
\text { Kommentar }\end{array}$} \\
\hline $\begin{array}{l}\text { Code } \\
\text { Kod }\end{array}$ & $\begin{array}{l}\text { Status } \\
\text { Status }\end{array}$ & $\begin{array}{l}\text { Year } \\
\text { Ar }\end{array}$ & $\begin{array}{l}\text { Country } \\
\text { Land }\end{array}$ & $\begin{array}{l}\text { Year } \\
A r\end{array}$ & $\begin{array}{l}\text { Country } \\
\text { Land }\end{array}$ & $\begin{array}{l}\mathrm{Km} \\
K m\end{array}$ & \\
\hline $1 \mathrm{C} 41$ & cygnet & 2004 & Latvia & 2009 & Latvia & 15 & \\
\hline $2 \mathrm{C} 33$ & breeder & 2005 & Latvia & 2007 & Estonia & 261 & \\
\hline $2 \mathrm{C} 38$ & cygnet & 2005 & Latvia & 2006 & Latvia & 15 & Moulted in September \\
\hline $2 \mathrm{C} 38$ & cygnet & 2005 & Latvia & 2007 & Latvia & 15 & Moulted in September \\
\hline $2 \mathrm{C} 44$ & breeder & 2005 & Latvia & 2008 & Latvia & 0 & No re-sighting after moult \\
\hline $2 \mathrm{C} 49$ & breeder & 2005 & Latvia & 2008 & Latvia & 0 & Seen with cygnets after moult \\
\hline $2 \mathrm{C} 49$ & breeder & 2005 & Latvia & 2010 & Latvia & 0 & Lost mate in winter $2009 / 2010$ \\
\hline $2 \mathrm{C} 83$ & cygnet & 2006 & Latvia & 2011 & Estonia & 241 & \\
\hline $2 \mathrm{C} 87$ & breeder & 2006 & Latvia & 2008 & Estonia & 241 & \\
\hline $3 \mathrm{C} 06$ & cygnet & 2006 & Latvia & 2012 & Latvia & 19 & Moulted in middle of September \\
\hline $3 \mathrm{C} 20$ & cygnet & 2006 & Latvia & 2007 & Latvia & 2.2 & \\
\hline $3 \mathrm{C} 41$ & cygnet & 2006 & Latvia & 2008 & Latvia & 0 & \\
\hline $3 \mathrm{C} 80$ & breeder & 2007 & Latvia & 2009 & Latvia & 12 & \\
\hline $3 \mathrm{C} 94$ & cygnet & 2006 & Latvia & 2007 & Latvia & 0 & \\
\hline $4 \mathrm{C} 00$ & breeder & 2007 & Latvia & 2008 & Latvia & 15 & Seen with cygnets after moult \\
\hline $4 C 39$ & cygnet & 2006 & Latvia & 2008 & Estonia & 215 & \\
\hline $4 \mathrm{C} 48$ & cygnet & 2007 & Latvia & 2008 & Latvia & 37 & No re-sighting after moult \\
\hline $4 \mathrm{C} 70$ & cygnet & 2007 & Latvia & 2009 & Latvia & 0.1 & \\
\hline $6 \mathrm{C} 62$ & breeder & 2008 & Latvia & 2009 & Latvia & 21 & Lost mate in winter $2008 / 2009$ \\
\hline $6 \mathrm{C} 62$ & breeder & 2008 & Latvia & 2011 & Estonia & 266 & \\
\hline $6 \mathrm{C} 78$ & breeder & 2007 & Latvia & 2009 & Latvia & 12 & \\
\hline $7 \mathrm{C} 171$ & cygnet & 2008 & Lithuania & 2011 & Lithuania & 1 & \\
\hline $7 \mathrm{C} 17$ & cygnet & 2008 & Lithuania & 2012 & Lithuania & 1 & \\
\hline 7C 181 & cygnet & 2008 & Lithuania & 2009 & Lithuania & 1 & No re-sighting after moult \\
\hline $7 \mathrm{C} 211$ & cygnet & 2008 & Lithuania & 2009 & Lithuania & 1 & \\
\hline 7C21 & cygnet & 2008 & Lithuania & 2010 & Lithuania & 1 & \\
\hline $7 \mathrm{C} 21$ & cygnet & 2008 & Lithuania & 2011 & Lithuania & 1 & \\
\hline $7 \mathrm{C} 21$ & cygnet & 2008 & Lithuania & 2012 & Lithuania & 1 & \\
\hline $7 \mathrm{C} 221$ & cygnet & 2008 & Lithuania & 2009 & Lithuania & 1 & \\
\hline $7 \mathrm{C} 22$ & cygnet & 2008 & Lithuania & 2010 & Lithuania & 1 & \\
\hline $7 \mathrm{C} 22$ & cygnet & 2008 & Lithuania & 2011 & Lithuania & 1 & \\
\hline $0 \mathrm{E} 05$ & breeder & 2008 & Latvia & 2010 & Latvia & 6 & Moulted without mate (dead?) \\
\hline 0E98 & breeder & 2009 & Latvia & 2009 & Latvia & 25 & Moulted in late August \\
\hline $1 \mathrm{E} 22$ & cygnet & 2009 & Latvia & 2011 & Latvia & 81 & \\
\hline $1 \mathrm{E} 22$ & cygnet & 2009 & Latvia & 2012 & Latvia & 81 & \\
\hline $2 \mathrm{H} 091$ & cygnet & 2010 & Lithuania & 2012 & Lithuania & 1 & \\
\hline $2 \mathrm{H} 16$ & cygnet & 2010 & Lithuania & 2011 & Lithuania & 25 & \\
\hline $2 \mathrm{H} 17$ & cygnet & 2010 & Lithuania & 2012 & Lithuania & 25 & \\
\hline $2 \mathrm{H} 17$ & cygnet & 2010 & Lithuania & 2011 & Lithuania & 25 & \\
\hline $2 \mathrm{H} 22$ & cygnet & 2010 & Lithuania & 2012 & Lithuania & 40 & \\
\hline $2 \mathrm{H} 36$ & cygnet & 2010 & Lithuania & 2011 & Lithuania & 0.2 & \\
\hline $2 \mathrm{H} 37$ & cygnet & 2010 & Lithuania & 2011 & Lithuania & 0.2 & \\
\hline $2 \mathrm{H} 38$ & cygnet & 2010 & Lithuania & 2011 & Lithuania & 0.2 & \\
\hline $2 \mathrm{H} 99$ & cygnet & 2011 & Lithuania & 2012 & Lithuania & 25 & \\
\hline $3 \mathrm{H} 18$ & cygnet & 2011 & Lithuania & 2012 & Lithuania & 25 & \\
\hline $3 \mathrm{H} 31^{1}$ & cygnet & 2011 & Lithuania & 2012 & Lithuania & 1 & \\
\hline $3 \mathrm{H} 34^{1}$ & cygnet & 2011 & Lithuania & 2012 & Lithuania & 1 & \\
\hline 1R88 & cygnet & 2008 & Poland & 2010 & Lithuania & 191 & \\
\hline $3 \mathrm{R} 03$ & cygnet & 2004 & Poland & 2005 & Latvia & 658 & \\
\hline $3 R 15$ & cygnet & 2007 & Poland & 2008 & Latvia & 715 & \\
\hline 3R61 & cygnet & 2007 & Poland & 2012 & Lithuania & 192 & \\
\hline 3R65 & cygnet & 2008 & Poland & 2010 & Lithuania & 193 & \\
\hline 3R65 & cygnet & 2008 & Poland & 2011 & Lithuania & 193 & \\
\hline 6R04 & cygnet & 2001 & Germany & 2002 & Latvia & 836 & \\
\hline
\end{tabular}

\footnotetext{
${ }_{1}^{1}=$ these birds had the same parents. Dessa fäglar hade samma föräldrar.
} 
site for staging during the pre- and/or post-moult periods. Of surviving birds that did not breed in the year after marking, $74 \%(\mathrm{~N}=85)$ were not found moulting in the Baltic States. The nesting site was established for seven of the marked birds in a subsequent year; six of these were found in the same country as where they had been marked. About one third of the marked individuals were not recorded at all during the pre-moult, moult or post-moult periods in subsequent years.

The places of origin of marked Whooper Swans found moulting as non-breeders in the Baltic States fell into two distinct groups. The majority originated from the immediate neighbourhood of the moulting site, most of them from within $25 \mathrm{~km}$, the others from countries, including Germany and Poland, situated at a more southern latitude than the moulting site (Table 3). Distances between sites of hatching or breeding and moulting for these two groups ranged $0-81 \mathrm{~km}$ and $191-836 \mathrm{~km}$, respectively.

Of Whooper Swans hatched in Latvia, fitted with a neck collar as cygnet and known to be alive at the beginning of the moulting season, the bird moulted in the Baltic States in 1.1\% ( $=351)$ and $1.3 \%$ $(\mathrm{N}=521)$ of the cases in their $2^{\text {nd }}$ and $3^{\text {rd }}-6^{\text {th }}$ calendar year, respectively (Table 3 ). The corresponding figure in the 2nd calendar year for individuals hatched in Lithuania and Baltoji Voke region was $12 \%(\mathrm{~N}=68)$ and $47 \%(\mathrm{~N}=17)$, respectively. Baltoji Voke is the only region in Lithuania in which birds marked as cygnets have moulted locally. Seven of the 15 individuals hatched in the Baltoji Voke region and subsequently recorded moulting locally had the same parents. In this region, the number of breeding Whooper Swan pairs has increased in parallel with the number of moulting non-breeders, from one pair in 1998 to 16 pairs in 2012 and from one moulter in 1997 to 80 moulters in 2012.

Of Whooper Swans fitted with neck collars while breeding, two birds were found moulting after having lost their mate during the preceding winter (Table 3). A third bird might have belonged to the same category as it moulted without a mate. One individual was not seen after the moult. In 2008, a breeding pair (2C49-4C00) moulted in Skrunda fishponds without cygnets but were seen together with their four young, of which three were fitted with neck collars, in Satini fishponds in September.

Unlike the Baltic States there are no large fishpond complexes in South Sweden. The habitat most similar to a fishpond complex is a shallow eutrophic lake. Numbers of non-breeding Whooper Swans recorded in five such lakes during the years
Table 4. Maximum counts of non-breeding Whooper Swans in Lakes Hornborgasjön, Tåkern, Kvismaren, Krankesjön and Björkesåkrasjön during the periods 29 June-31 July (to the left of the slash) and $1 \mathrm{Au}-$ gust-14 September (to the right of the slash) in the years 1982-2012. Sources: Hornborgasjön, Tåkern and Kvismaren - Svalan; Krankesjön - Hans Källander; Björkesåkrasjön - Hakon Kampe-Persson.

Maxsiffror för antalet ickehäckande sångsvanar $i$ Hornborgasjön, Tåkern, Kvismaren, Krankesjön och Björkesåkrasjön under perioderna 29 juni-31 juli (till vänster om snedstrecket) och 1 augusti-14 september (till höger om snedstrecket) åren 1982-2012. Källor: Hornborgasjön, Tåkern och Kvismaren - Svalan; Krankesjön - Hans Källander; Björkesåkrasjön Hakon Kampe-Persson.

\begin{tabular}{|c|c|c|c|c|c|}
\hline & 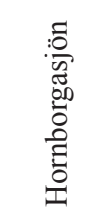 & 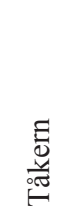 & 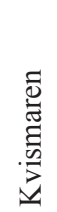 & 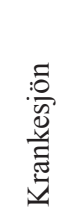 & 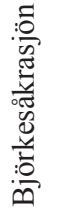 \\
\hline 1982 & & & $1 / 0$ & - & - \\
\hline 1983 & & & & - & - \\
\hline 1984 & & $2 / 0$ & & - & - \\
\hline 1985 & & & $0 / 1$ & 0 & - \\
\hline 1986 & & & & 0 & - \\
\hline 1987 & & & & $0 / 1$ & - \\
\hline 1988 & & & & $2 / 0$ & - \\
\hline 1989 & $2 / 1$ & $2 / 0$ & & 0 & - \\
\hline 1990 & & $2 / 0$ & & 0 & - \\
\hline 1991 & $0 / 2$ & & & 0 & - \\
\hline 1992 & & & & $4 / 0$ & - \\
\hline 1993 & & & & 0 & - \\
\hline 1994 & & & $2 / 0$ & $0 / 6$ & \\
\hline 1995 & $1 / 6$ & & $6 / 0$ & $2 / 2$ & - \\
\hline 1996 & $2 / 4$ & & $3 / 2$ & $1 / 3$ & $0 / 1$ \\
\hline 1997 & $4 / 4$ & & & - & - \\
\hline 1998 & $2 / 4$ & & & $0 / 2$ & $0 / 1$ \\
\hline 1999 & $2 / 4$ & $2 / 0$ & & $2 / 2$ & 0 \\
\hline 2000 & $3 / 4$ & & & - & - \\
\hline 2001 & $11 / 9$ & $3 / 3$ & $0 / 1$ & 0 & 0 \\
\hline 2002 & $15 / 56$ & $0 / 2$ & & $4 / 1$ & - \\
\hline 2003 & $-/ 54$ & $0 / 10$ & $3 / 2$ & $0 / 2$ & - \\
\hline 2004 & $8 / 44$ & $0 / 3$ & & 0 & $0 / 1$ \\
\hline 2005 & $21 / 73$ & $4 / 2$ & $0 / 4$ & 0 & 0 \\
\hline 2006 & $-/ 29$ & & 0 & $2 / 0$ & $3 / 0$ \\
\hline 2007 & $-/ 88$ & $0 / 11$ & $0 / 3$ & 0 & - \\
\hline 2008 & $-/ 57$ & $0 / 1$ & $0 / 2$ & $0 / 1$ & 0 \\
\hline 2009 & $-/ 75$ & $2 / 22$ & $1 / 1$ & $2 / 2$ & - \\
\hline 2010 & $63 / 75$ & & $0 / 1$ & 0 & $0 / 2$ \\
\hline 2011 & $-/ 133$ & & $3 / 1$ & $9 / 1$ & 0 \\
\hline 2012 & $34 / 160$ & $1 / 2$ & $2 / 2$ & $0 / 3$ & $2 / 1$ \\
\hline
\end{tabular}


1982-2012 are shown in Table 4. In one of these lakes, Hornborgasjön, numbers increased markedly during that period of time. No Whooper Swan has moulted in Lake Krankesjön during the last three decades (Hans Källander in litt.) but whether or not the species has moulted in any of the other four lakes is unknown.

\section{Discussion}

Three different moulting strategies are used by non-breeding Whooper Swans in the south-eastern Baltic region. The majority migrate to traditional moulting grounds in Russia. About $99 \%$ of birds hatched in Latvia belong to this group (Boiko \& Kampe-Persson 2012). Distances between hatching and moulting sites for three Latvian birds ranged 1,283-1,455 km. Other non-breeders carry through a moult migration but stop to moult in the Baltic States. The third group consists of birds that moult in a fishpond close to their site of hatching or breeding. That a moulting site attracts birds from both its neighbourhood and more distant breeding grounds has been shown for the Mute Swan in Denmark (Anders-Harild 1990).

The Whooper Swan also moults at several sites in Poland (Wieloch \& Sikora 2008) but only scattered data are available from that country (Maria Wieloch in litt.). In 2007-2008, the number of moulting non-breeders in the Barycz Valley alone amounted to $25-38 \%$ of the estimated number of non-breeders in the Polish population (for data, see Wieloch \& Sikora 2008). With a corresponding figure of 10\% for the Baltic States (this study) nonbreeders from the Polish population seem to be more likely to moult close to their site of hatching/ breeding. However, some of the birds found moulting in Poland might have originated from Germany (Degen \& Heinicke 2007).

Genetic studies have demonstrated a mixed origin of the Whooper Swans that breed in Latvia and Lithuania today (Butkauskas et al. 2012). After having been gone for more than a century the Whooper Swan started to regain former breeding grounds in the Baltic States and in Poland in 1973 (Wieloch \& Sikora 2008, Boiko \& Kampe-Persson 2010). Also individuals of captive origin might have been recruited into this population. There is a naturalised population in Germany and releases of captive birds have occurred also in other parts of Germany (Bauer \& Woog 2008). Recruits of captive origin might be the cause of the prevalence of Whooper Swans in the Baltoji Voke region to moult locally and maybe also of the large numbers of non-breeding birds moulting in Poland. Birds of captive origin, lacking a tradition of long-distance moult migration, might be prone to remain and moult at the breeding grounds. However, releases of birds of captive origin in South Sweden in the 1930s-1970s (Hansson 1968, Jansson 1989, Mathiasson 1992) did not give rise to any moulting congregations of non-breeding Whooper Swans. Besides, the swans at Baltoji Voke do not lack experience of long-distance migration per se, because many of them winter in The Netherlands, 1,200 km from the breeding grounds,

The hypothesis that non-breeding Whooper Swans moulting in the Baltic States are birds unable to undertake a moult migration to Russia are partially supported by life-history data presented in this study. Several birds apparently died during moult, because more than a tenth of the individuals marked while moulting were not seen after the moulting season. Among survivors that did not breed in the year after marking, three fourths were not found moulting in the Baltic States. However, no less than one third of the survivors returned to moult at the very same moulting site as where they had been marked, some of them up to five times. That figure is hard to fit into a "bad condition" hypothesis. Furthermore, individuals unable to carry through a moult migration ought to have been found moulting also in South Sweden. So, also other explanations must be sought. The most likely one seems to be access to large, shallow waterbodies, offering an abundance of additional food but lacking human disturbance.

Although a large proportion was made up of $2^{\text {nd }}$ calendar year birds, the proportion of $2^{\text {nd }}$ calendar year birds that remained to moult in the Baltic States was not higher than that of $3^{\text {rd }}-6^{\text {th }}$ calendar year birds. In other studies, differences in the choice of moulting site between $2^{\text {nd }}$ calendar year and older birds have been found (Mineev 1986, Mineev 2005, Degen \& Heinicke 2007). Brazil (2003) assumed that failed breeders could join moulting flocks in summer. This study showed that both unsuccessful and successful breeders used fishponds for moulting, some pairs even before their young could fly.

The lack of known moulting sites for non-breeding Whooper Swans in South Sweden can be due to either that moulting Whooper Swans have been overlooked or that necessary requirements for moulting are lacking. Moulting Whooper Swans may pass unnoticed if they moult together with large numbers of Mute Swans or at a site used for staging before and after moult. The two swan spe- 
cies very likely have similar requirements of food and security during wing moult. In South Sweden, moulting Whooper Swans may of that reason be looked for at sites where large numbers of Mute Swans moult. The fact that Whooper Swans at one and the same moulting site can start to moult from the end of June to the end of August in the same season makes it hard to interpret count data. Birds joining a moulting flock in August can be made up of both un-moulted birds and birds that have moulted at their respective breeding site (this study). Available count data from Lake Hornborgasjön strongly indicate that a large part of the Whooper Swans found in that lake in summer arrives during the second half of the moulting period. Consequently, it seems likely that most of the Whooper Swans recorded in Lake Hornborgasjön in summer already have moulted their wing feathers before they arrive at the lake.

There are no large shallow water-bodies in South Sweden offering additional food like the fishponds in Latvia and Lithuania. The natural food sources in shallow eutrophic lakes may be sufficient for moulting Whooper Swans however. But is the level of human disturbance low enough at the potential moulting sites? As a result of intense yearround persecution up to the early $20^{\text {th }}$ century, the Whooper Swan became an extremely rare and shy bird in Sweden (Brusewitz 1971). At the same time as the species regained former breeding grounds after its protection in 1926, it slowly became less shy. But has the species lost enough shyness to moult in South Sweden? The large numbers of Whooper Swans found in Lake Hornborgasjön in July some years strongly suggest that this lake is a moulting site for at least some non-breeders. But even if non-breeding Whooper Swans regularly moult in that lake, their numbers cannot account for more than a few percent of the total number of non-breeders in the South Swedish population. For the vast majority of the non-breeders in this population it is obviously more profitable to undertake a moult migration of at least 2,750-4,200 km than to remain and moult in South Sweden.

\section{Acknowledgements}

For providing observations of moulting swans, and for published and unpublished data, our sincere thanks go to all persons named in the text and legends, and to Saulius Švažas and Sören Svensson as well. We are grateful to all members of the different ringing expeditions for help in catching the swans, and to the dedicated amateur and professional ornithologists who always keep a keen eye open for marked Whooper Swans.

\section{References}

Andersen-Harild, P. 1990. Migration of Cygnus olor ringed in Denmark in winter and during moult. Pp. 120-131 in Proceedings of the second international swan symposium in Sapporo, Japan, February 1990 (Matthews, G.V.T. \& Smart, M., eds.). International Waterfowl Research Bureau, Gloucestershire, England.

Anonymous 2011. About Finland's national bird. www.looduskalender.ee (access date 17 July 2012).

Axbrink, M. 1999. Sångsvanen ökar, resultat från riksinventeringen 1997. Vår Fågelvärld 58(3): 10-16.

Bauer, H.-G. \& Woog, F. 2008. Non-native and naturalized bird species (neozoa) in Germany, part I: occurrence, population size and status. Vogelwarte 46: 157-194. (German with English summary),

Baumanis, J. 2004. Ūdensputnu ligzdošanas apstāklı uzlabošanas plāns Lubānas mitrāja kompleksa zivju diķos. Madonas rajona padome, Nagl̦i.

Baumanis, J., Kazurbiernis, J. \& Kazurbierne, M. 1999. Ligzdojošo ūdensputnu skaita dinamika Lubāna ezeram pieguļošajos zivju diķos 1975. - 1999. gadā. Latvijas Universitātes Biologijas Institūts, Salaspils.

Boiko, D. 2005. Whooper Swan Cygnus cygnus breeding in Latvia in 2004. Materials of Third International Conference: Research and conservation of biological diversity in the Baltic region, p. 42. Daugavpils University, Daugavpils, Latvia.

Boiko, D. 2008. Territorial and temporal distribution of Whooper Swan Cygnus cygnus marked with neck collars in Latvia in 2003-2005. Acta Universitatis Latviensis, Biology 745: 53-61.

Boiko, D. \& Kampe-Persson, H. 2010. Breeding Whooper Swans Cygnus cygnus in Latvia, 1973-2010. Wildfowl 60: $168-177$.

Boiko, D. \& Kampe-Persson, H. 2012. Moult migration of Latvian Whooper Swans Cygnus cygnus. Ornis Fennica 89: 273-280.

Brazil, M. 2003. The Whooper Swan. T. \& A.D. Poyser, London.

Brusewitz, G. 1971. Jakt och Jägare. Bokförlaget Bra Böcker, Höganäs.

Butkauskas, D., Švažas, S., Tubelytė, V, Morkūnas, J., Sruoga, A., Boiko, D., Paulauskas, A., Stanevičius, V. \& Baublys, V. 2012 Coexistence and population genetic structure of the whooper swan Cygnus cygnus and mute swan Cygnus olor in Lithuania and Latvia. Central European Journal of Biology 7: 886-894.

Degen, A. \& Heinicke, T. 2007. Whooper Swan Cygnus cygnus. Pp. 44-56 in Bird Migration in Eastern Germany - Waterbirds part 1 (Heinicke, T. \& Köppen, U., eds.). Berichte Vogelwarte Hiddensee 18 (SH), Greifswald. (German with English summary).

Dement'ev, G.P. 1935. Birds in the Kanin Peninsula. Collection of works of the Zoological Museum 2: 23-55. (In Russian).

Einarsson, Ó. 1996. Breeding biology of the Whooper Swan and factors affecting its breeding success, with notes on 
its social dynamics and life-cycle in the wintering range. $\mathrm{PhD}$ thesis. University of Bristol.

Elts, J., Kuresoo, A., Leibak, E., Leito, A., Leivits, A., Lilleleht, V., Luigujõe, L., Mägi, E., Nellis, R., Nellis, R. $\&$ Ots, M. 2009. Status and numbers of Estonian birds, 2003-2008. Hirundo 22: 3-31.

Garðarsson, A. \& Skarphéðinsson, K.H. 1984. A census of the Icelandic Whooper Swan population. Wildfowl 35: 37-47.

Haapanen, A. 1991. Whooper Swan Cygnus c. cygnus population dynamics in Finland. In Proceedings of the Third IWRB International Swan Symposium (Sears, J. \& Bacon, P.J., eds.), Oxford 1989. Wildfowl, Supplement No. 1: 137-141.

Hansson, L. 1968. Sångsvanen som skånsk häckfågel. Meddelanden från Skånes ornitologiska förening 7: 45-50.

Jansson, T. 1989. Knångsvanen - Kalmars egen "fula ankunge". Fåglar i Östra Småland 1: 5-6.

Kampe-Persson, H. 2010. Naturalised geese in Europe. Ornis Svecica 20: 155-173.

Kear, J. 1972. Reproduction and family life. Pp. 79-124 in The Swans (Scott, P. \& The Wildlife Trust, eds.). Michael Joseph, London.

Litvin, K. \& Gurtovaya, E.N. 2003. Moult migration of the Whooper Swan at the Kanin Peninsula. Pp. 106-107 in Management and conservation of waterfowl populations in Northern Eurasia (with special focus on the White Sea - Baltic flyway): Abstracts, presented to the International symposium April 2003, Olonets, Karelia, Russia (Zimin, V.B., Popovkina, A.B. \& Syroechkovski, Jr. E.E., eds.). Goose, Swan and Duck Study Group of Northern Eurasia, Institute of Biology, Karelian Research Centre of RAS, Department of Biological Science, Russian Academy of Science, Petrozavodsk. (In Russian).

Luigujõe, L., Kuresoo, A. \& Leivits, A. 2002. Numbers and Distribution of Whooper Swans Breeding, Wintering and on Migration in Estonia, 1990-2000. Waterbirds 25 (Special Publication 1): 61-66.

Mathiasson, S. 1992. Hybrider mellan knölsvan och sångsvan. Göteborgs Naturhistoriska museum. Årstryck 1992: 43-59. (Swedish with English summary).

Meriste, M., Kirsimäe, K. \& Freiberg, L. 2012. Relative SeaLevel Changes at Shallow Coasts Inferred from Reed Bed Distribution over the Last 50 Years in Matsalu Bay, the Baltic Sea. Journal of Coastal Research 28: 1-10.

Mineev, Yu.N. 1986. Seasonal distribution and the numbers of swans in the north-east of the European part of the USSR. Bulletin of the Moscow Society of Nature Explorers, Department of Biology 91(3): 19-27. (Russian with English summary).

Mineev, O.Yu. 2005. Waterfowl of Malozemelskaya tundra and Pechora river delta. Ural Division of Russian Academy of Science, Yekaterinburg. (In Russian).

Morkūnas, J., Švažas, S. \& Raudonikis, L. 2010. Some features of breeding and migration of Whooper Swan (Cygnus cygnus) ringed in Lithuania. Pp. 58-59 in Biodiversity and Functioning of Aquatic Ecosystems in the Baltic Sea Region. Proceedings of $5^{\text {th }}$ International Student Conference, October 2010, Palanga, Lithuania.

Ottosson, U., Ottvall, R., Elmberg, J., Green, M., Gustafsson, R., Haas, F., Holmqvist, N., Lindström, Å., Nilsson, L., Svensson, M., Svensson, S. \& Tjernberg, M. 2012. Fåglarna i Sverige - antal och utbredning. Sve- riges Ornitologiska Förening. (Swedish with English summary).

Owen, M. 1980. Wild Geese of the world. B T Batsford, London.

Rees, E.C., Black, J.M., Spray, C.J. \& Thorisson, S. 1991. Comparative study of the breeding success of Whooper Swans Cygnus cygnus nesting in upland and lowland regions of Iceland. Ibis 133: 365-373.

Schadilov, Yu.M., Rees, E.C., Belousova, A.V. \& Bowler, J.M. 2002. Annual Variation in the Proportion of Whooper Swans and Bewick's Swans Breeding in Northern European Russia. Waterbirds 25 (Special Publication 1): 86-94.

Strazds, M. \& Kuuze, J. (eds.) 2006. Birds of Ķemeri National Park. Jumava, Riga. (Latvian with English summary).

Švažas, S. \& Stanevičius, V. 2000. The waterbirds of the large fish pond complexes in Lithuania. Acta Ornithologica 35: 45-49.

Švažas, S. \& Kozulin, A. (eds.) 2002. Waterbirds of large fishponds of Belarus and Lithuania. Migratory Birds of the Western Palearctic (OMPO) \& Institute of Ecology publishers, Vilnius.

Svensson, S., Svensson, M. \& Tjernberg, M. 1999. Svensk fågelatlas. Vår Fågelvärld, supplement 31, Stockholm.

Valkama, J., Saurola, P. \& Velmala, W. 2012. The Finnish Bird Ringing Atlas. Ministry of environment and Finnish Museum of Natural History, Helsinki. (Finnish with English summary).

Väisänen, R.A., Hario, M. \& Saurola, P. 2011. Population estimates of Finnish birds. In The Third Finnish Breeding Bird Atlas (Valkama, J., Vepsäläinen, V. \& Lehikoinen, A., eds). Finnish Museum of Natural History \& Ministry of Environment, Helsinki. //atlas3.lintuatlas.fi/english (access date 12 March 2012).

Wahl, J. \& Degen, A. 2009. Numbers and distribution of Whooper Swan Cygnus cygnus and Bewick's Swan C. bewickii in Germany in the winter season 2004/2005. Vogelwelt 130: 1-24. (German with English summary).

Wieloch, M. \& Czyź, S. 2008. Preliminary results of ringing of the Whooper Swan Cygnus cygnus breeding in Poland and the origin of birds ringed abroad and recovered in Poland. Abstract. The 1st European Swan Conference, Swan Ecology and Biology, October 2008, Daugavpils, Latvia.

Wieloch, M. \& Sikora, A. 2008. Expansion and present status of Whooper Swan Cygnus cygnus in Poland. Abstract. The $1^{\text {st }}$ European Swan Conference, Swan Ecology and Biology, October 2008, Daugavpils, Latvia.

\section{Sammanfattning}

Sångsvanen tillhör den grupp av fåglar som ruggar samtliga vingpennor samtidigt, vilket gör den flygoförmögen under 5-6 veckor. Vingpenneruggningen sker vanligtvis under en period som sträcker sig från slutet av juni till mitten av september. Eftersom sångsvanen inte börjar häcka förrän vid 4-6 års ålder består en stor andel av populationen av ickehäckare. Varje år är det omkring två tredjedelar av individerna som inte skrider till häckning.

Hos de flesta svanarter samlas ickehäckarna i flockar som ruggar vingpennorna i närheten av 
häckningsområdena. Sångsvanen i Östersjöområdet passar emellertid inte in i det normala mönstret. Inga ruggningskoncentrationer har konstaterats $\mathrm{i}$ Fennoskandien, endast grupper på upp till 18 lokala fåglar i stora myrkomplex. Dessa grupper kan inte på långt när svara för samtliga ickehäckare eftersom antalet häckande fåglar i Sverige och Finland överstiger 10400 par. Det har antagits att de fennoskandiska ickehäckarna ruggar i Ryssland, förmodligen i Arkhangelskregionen, men bortsett från fyra märkta individer saknas direkta bevis. I Baltikum och Polen finns åtminstone en ruggningslokal för fler än 20 individer i vardera land. I Sydsverige, den del av landet som ligger på samma breddgrader som Baltikum, finns däremot inte någon känd ruggningslokal över huvud taget.

Vårt syfte var att ge en komplett beskrivning av utbredning och antal av ruggande ickehäckande sångsvanar i Baltikum samt att genomföra en första analys av levnadshistorier för individer som märkts, eller märkta individer som observerats rugga, på de olika ruggningslokalerna i Baltikum. Avslutningsvis ville vi se om en kombination av dessa uppgifter kunde förklara varför det inte finns någon känd ruggningslokal för ickehäckande sångsvanar i Sydsverige.

Första gången ruggning av ickehäckande sångsvanar konstaterades i Lettland var 1989, i Estland 1993 och i Litauen 1997. Ruggning har rapporterats från 13 lokaler i Baltikum, tre i Estland samt fem vardera i Lettland och Litauen. Samtliga lokaler i Estland samt Kaltene ugörs av kustlokaler, Kaņieris är en tidigare utdikad sjö medan övriga lokaler i Lettland och samtliga lokaler i Litauen utgörs av fiskdammar. Ickehäckande sångsvanar har i Baltikum alltid ruggat tillsammans med knölsvanar, där flockarna av knölsvan på kustlokalerna räknat upp till 800 fåglar och i fiskdammarna upp till 300 fåglar. Matsalu Bay, Kaņieris och fiskdammarna är stora, tämligen grunda vattenområden, kantade av vassbälten och buskmarker av varierande bredd. I fiskdammarna utgörs en stor del av de ruggande svanarnas föda av fiskfoder. Ägarna börjar på de flesta lokaler utfodra karparna med majs i slutet av april eller början av maj men i Skrunda först $\mathrm{i}$ juni. Inverkan av mänsklig störning är låg i fiskdammarna eftersom allmänhetens tillträde är begränsat.

Totala antalet ruggande ickehäckande sångsvanar i Baltikum har ökat från minst 83 fåglar 2003 till minst 187 fåglar 2012. Antalet har dock hållit sig tämligen stabilt omkring $10 \%$ av det beräknade antalet ickehäckare i den baltiska sångsvanpopulationen. Vid de lokaler som utnyttjats årligen under det senaste decenniet har antalet ruggare ökat kraftigt $\mathrm{i}$ antal vid Baltoji Voke, medan antalen hållit sig tämligen stabila vid de övriga fyra.

Av de ruggande sångsvanar som fångades för halsringmärkning var 33\% av de lettiska och $67 \%$ av de litauiska $2 \mathrm{~K}$ fåglar. Av de märkta ruggarna var det $12 \%$ av $3 \mathrm{~K}+$ fåglarna och $16 \%$ av $2 \mathrm{~K}$ fåglarna som inte observerades efter ruggningssäsongen. Bland dem som överlevde ruggningssäsongen var det $33 \%$ som återvände för att rugga på den lokal där de märkts, en del upp till fem gånger. Ytterligare $16 \%$ utnyttjade ruggningslokalen som rastlokal före och/eller efter ruggningen medan omkring en tredjedel av individerna inte observerades över huvud taget under sommarhalvåret under åren efter märkåret. Bland de överlevande fåglarna som inte häckade under säsongen efter märkningen var det $74 \%$ som inte ruggade i Baltikum.

Stamorterna för halsringmärkta sångsvanar som konstaterats rugga som ickehäckare i Baltikum föll i två gupper. Majoriteten var födda eller häckade i ruggningslokalens omedelbara närhet $(0-81 \mathrm{~km})$ medan övriga kom från länder, inklusive Tyskland och Polen, på sydligare breddgrader än ruggningslokalen. De sistnämnda ruggade 191-836 km från den plats där de var födda eller häckade. Bland sångsvanar som halsringmärkts som ungar i Lettland, Litauen respektive Baltoji Voke regionen och som med säkerhet var vid liv den 1 maj året efter märkningen var det $1,1 \%, 12 \%$ respektive $47 \%$ som ruggade i Baltikum som $2 \mathrm{~K}$ fåglar.

Eftersom det saknas stora fiskdammskomplex i Sydsverige anges som jämförelse istället förekomsten av sångsvan under ruggningstid i fem vassjöar, den lokaltyp som är mest lik de baltiska fiskdammarna. I en av dessa sjöar, Hornborgasjön, har antalet sångsvanar ökat kraftigt under de senaste 30 åren. Under denna period har ingen ickehäckande sångsvan ruggat i Krankesjön, men om det har skett i någon av de andra sjöarna är okänt.

Fåglar som ruggar vingpennorna samtidigt har två huvudkrav under den tid de saknar flygförmåga, nämligen tillgång på föda och säkerhet från rovdjur. Att det finns ett stort antal potentiella ruggningslokaler för sångsvan i Sydsverige framgår av det stora antalet häckande par, ty häckande fåglar ruggar vanligtvis sina vingpennor på häcklokalen innan ungarna blir flygga. Sångsvanen är dock starkt territoriel under häckningen, varför det sällan finns några andra svanar där det finns ett häckande sångsvanpar. Frågan är därför om det finns andra lokaler som uppfyller minimikraven för ruggande sångsvanar.

Eftersom ruggande sångsvanar lätt förbises om 
de ruggar tillsammans med numerärt talrikare knölsvanar kan det löna sig att noggrannt spana igenom svanflockar på de lokaler där knölsvanen av tradition ruggar i stora antal. Skulle sångsvanen börja rugga på en lokal som normalt utnyttjas som rastlokal före och efter ruggningen, kanske också som häcklokal, kan det ibland förbises att arten faktiskt ruggar på lokalen. Det faktum att sångsvanar på en och samma lokal under en och samma säsong kan börja rugga från slutet av juni till slutet av augusti komplicerar dessutom tolkningen av inventeringsdata. Individer som dyker upp på en lokal i augusti och september kan nämligen redan ha ruggat sina vingpennor på häcklokalen. Detta kan gälla för majoriteten av de sångsvanar som sommartid rapporterats från Hornborgasjön. Förekomsten av flockade sångsvanar redan i juli är däremot en stark indikation på att arten faktiskt ruggar $\mathrm{i}$ Hornborgasjön. 